\title{
STUDI DAMPAK PEMBANGUNAN DAERAH DI REGIONAL KALIMANTAN $^{1}$
}

\author{
Tim Kajian \\ Pusat Kajian dan Pendidikan dan Pelatihan Aparatur III - Lembaga \\ Administrasi Negara \\ Jl. H.M. Ardhans (Ring Road III) Samarinda
}

\begin{abstract}
The objective of this study is searching the outcomes of development implementation conducts by local governments in Kalimantan. This research uses descriptive analysis method and qualitative approach. The data is collected by interview with key informants in local governments and supported by secondary data. The result of this research are firstly, development in regional of Kalimantan remains great problems. It can be seen that development performance in several regions are still supported by exploitation on non-renewable natural resources, that has environmental risk. In other hand, several regions which has no natural resources meet trouble in accelerating their development performance. Even it still remains declining in economic growth and increasing in unemployment. Secondly, refer to regional planning document found that local governments tend to place short term output as main orientation in regional development, and not outcomes that should give long term benefits and impacts for the people.
\end{abstract}

Keywords : outcome, district's development, regional Kalimantan

\section{Intisari}

Tujuan studi ini adalah untuk mengetahui dampak dari implementasi perencanaan pembangunan daerah kabupaten di regional Kalimantan. Metode yang digunakan adalah analisis deskriptif dengan pendekatan kualitatif. Untuk mendapatkan data dilakukan melalui interview dan pengumpulan data sekunder. Kesimpulan yang dihasilkan meliputi beberapa hal yaitu pertama, bahwa secara umum implementasi pembangunan daerah di tingkat kabupaten masih menjadi tantangan yang berat. Hal ini terlihat di beberapa daerah yang memiliki kinerja pembangunan yang bagus ternyata ditopang oleh sumber daya alam yang tidak dapat diperbarui, dan seringkali mengabaikan faktor lingkungan. Sementara di daerah lain yang tidak bisa mengandalkan potensi sumber daya alam mengalami kesulitan untuk mengakselerasi

${ }^{1}$ Naskah diterima: 20 Mei 2011, revisi kesatu: 1 September 2011, revisi terakhir: 10 September 2011 
kinerja pembangunannya, bahkan masih ada daerah yang mengalami penurunan pertumbuhan ekonomi serta peningkatan jumlah pengangguran. Sementara dari aspek pembangunan fisik, pembangunan infrastruktur dasar khususnya jalan di beberapa kabupaten cenderung lambat. Kedua, dilihat dari dokumen perencanaan, realisasi pembangunan di beberapa kabupaten masih cenderung berorientasi pada keluaran (output) jangka pendek. Pemerintah daerah masih berorientasi pada pelaksanaan program dan kegiatan jangka pendek dan kurang memperhatikan manfaat dan dampak jangka panjang (dampak/outcomes) yang seharusnya bisa dinikmati oleh masyarakat.

Kata kunci : dampak, pembangunan daerah, regional Kalimantan

\section{A. PENDAhuluan}

Kalimantan dikenal sebagai salah satu sumber energi yang menopang perekonomian nasional. Namun pada kenyataannya pemerataan hasil pembangunan masih menjadi permasalahan utama di kawasan ini, baik pembangunan infrastruktur, sosial, ekonomi maupun sumber daya manusia (SDM). Di bidang infrastruktur, konektivitas jalur darat antar provinsi di Kalimantan belum sepenuhnya memadai, terutama jalur darat antara provinsi Kalimantan Tengah dengan Kalimantan Barat. Jalur perhubungan udara juga belum terkoneksi sepenuhnya sehingga bagi masyarakat Kalimantan Timur yang hendak bepergian ke Kalimantan Barat harus transip ke Jawa, demikian pula sebaliknya.

Jalur perhubungan udara juga belum terkoneksi sepenuhnya sehingga bagi masyarakat Kalimantan Timur yang hendak bepergian ke Kalimantan Barat harus transip ke Jawa, demikian pula sebaliknya.

Tingkat kemiskinan masyarakat di Kalimantan masih tinggi. Tercatat kemiskinan tahun 2008 di Kalimantan Barat merupakan yang tertinggi yaitu $9,02 \%$ dari total warga di provinsi tersebut, kemudian disusul Kalimantan Timur 7,66 \%, Kalimantan Tengah $6,77 \%$, dan Kalimantan Selatan 5,21 $\%$. Sedangkan Indeks Pembangunan Manusia (IPM) tahun 2008, Kalimantan Timur memiliki IPM yang tertinggi yaitu 74,52 , disusul Kalimantan Tengah 73,88, Kalimantan Selatan 68,72, dan Kalimantan Barat 68,17 .

Supply bahan kebutuhan pokok di Kalimantan juga sangat tergantung dari pulau lain bahkan negara lain. Kebutuhan bahan makanan pokok selama ini tergantung dari Jawa dan Sulawesi. Demikian juga kebutuhan barang-barang hasil industri. Di kawasan perbatasan dengan Malaysia, yaitu di wilayah utara Provinsi Kalimantan Timur yang berbatasan dengan Negara Bagian Sabah dan wilayah Barat Provinsi Kalimantan Barat yang berbatasan dengan Negara Bagian Serawak, transaksi perdagangan secara ilegal kerap terjadi. Hal ini tidak bisa sepenuhnya dipersalahkan kepada masyarakat karena pertimbangan efisiensi dan 
ekonomi. Bahkan di Kalimantan Barat, pasokan energi listrik belakangan disuplai dari Malaysia.

Penelitian yang berkaitan dengan dampak pembangunan daerah telah dilakukan berbagai pihak. Suryadi (2007) menulis tesis tentang Dampak Pembangunan Jalur Jalan Lintas Selatan terhadap Output Sektor Produksi dan Pendapatan Rumah Tangga Jawa Tengah. Penelitian ini menggunakan unit analisa Matrik Sistem Neraca Sosial Ekonomi (SNSE) sebagai alat analisis karena SNSE merupakan model analisis dampak (impact analysis model) yang memperlihatkan peran dampak pengganda (mulitple effect atau multilier impact) akibat dari suatu perubahan variabel eksogen (exogenous variable) terhadap variabel endogen (endogenous variable).

Penelitian yang dilakukan Suryadi ini menghasilan beberapa kesimpulan yaitu pertama, pembangunan Jalur Jalan Lintas Selatan Jawa Tengah akan memberikan dampak peningkatan output yang relatif lebih besar nilainya pada sektor produksi pertambangan, industri pengolahan kecuali makanan, listrik, gas dan air minum. (2) Pertanian tanaman pangan, peternakan, perikanan, industri makanan. Kedua, pembangunan Jalur Jalan Lintas Selatan Jawa Tengah akan memberikan dampak peningkatan pendapatan yang relatif lebih besar pada : (1) rumah tangga pengusaha tani. (2) rumah tangga golongan atas perkotaan. Ketiga, dampak e konomi Pembangunan Jalur Jalan Lintas Selatan Jawa Tengah lebih banyak dinikmati oleh kelompok rumah tangga menengah ke atas dan kelompok rumah tangga perkotaan.

Almasdi Syahza (tanpa tahun) melakukan penelitian tentang Dampak Pembangunan Perkebunan Kelapa Sawit Terhadap Multiplier Effect Ekonomi Pedesaan di Daerah Riau. Penelitian ini dilakukan melalui survey dengan metode Case Study and Field Research (penelitian kasus dan penelitian lapangan). Menghasilkan kesimpulan bahwa kegiatan perkebunan kelapa sawit di pedesaan menciptakan angka multiplier effect sebesar 2,48, terutama dalam lapangan pekerjaan dan peluang berusaha. Tingkat pertumbuhan kesejahteraan petani kelapa sawit di Riau pada tahun 1995 sebesar 0,49 yang berarti tingkat pertumbuhan kesejahteraan hanya meningkat sebesar 0,49 persen. Kemudian pada 2003 indek pertumbuhan kesejahteraan petani kelapa sawit meningkat menjadi 1,72. Hal ini menunjukkan bahwa pembangunan perkebunan kelapa sawit dapat meningkatkan perekonomian pedesaan.

Dari beberapa contoh realitas di Kalimantan dan juga hasil-hasil penelitian lain terdahulu di atas tersebut maka muncul pertanyaan, hasil pembangunan apa yang telah dinikmati oleh masyarakat dan seberapa besar dampak hasil-hasil pembangunan tersebut membawa perubahan yang lebih baik kepada masyarakat Kalimantan yang terkenal sebagai daerah sumber energi tersebut?

Oleh karena itu, tulisan ini bertujuan untuk mengetahui dampak 
dari implementasi perencanaan pembangunan daerah sebagaimana yang tertuang dalam dokumen perencanaan pembangunan daerahnya. Dalam hal ini sejauh mana dampak dari implementasi perencanaan pembangunan daerah jika ditinjau dari aspek ekonomi, sosial, dan lingkungan. Sehingga dapat dipelajari untuk menghasilkan rekomendasi perencanaan pembangunan selanjutnya.

\section{B. METODE PENELITIAN}

Metode yang digunakan adalah metode analisis deskriptif dengan pendekatan kualitatif. Sampel/lokus yang digunakan adalah 7 kabupaten di seluruh Kalimantan yang meliputi 4 provinsi yaitu Kabupaten Kutai Barat dan Kabupaten Berau di Kalimantan Timur, Kabupaten Kotabaru di Kalimantan Selatan, Kabupaten Kotawaringin Timur dan Kabupaten Barito Timur di Kalimantan Selatan, serta Kabupaten Sanggau dan Kabupaten Bengkayang di Kalimantan Barat.

Sedangkan pengumpulan data dilakukan dengan cara wawancara dan pengumpulan data-data sekunder. Wawancara dilakukan terhadap para key informant di tingkat pemerintah kabupaten, yang terlibat dalam pembuatan dan pelaksanaan kebijakan pemerintahan. Wawancara ini dilakukan untuk menyerap segala informasi yang berkaitan dengan perencanaan pembangunan di daerah dan hasil-hasilnya beserta permasalahan yang muncul dalam kegiatan tersebut. Dan data sekunder sebagai pendukung yang digunakan untuk melengkapi informasi yang dibutuhkan. Perpaduan kedua metode pengumpulan data tersebut diharapkan bisa melengkapi semua data yang diperlukan dalam melakukan analisis secara komprehensif.

\section{KERANGKA KONSEPTUAL}

1. Perencanaan Pembangunan Daerah

Perencanaan pembangunan merupakan fungsi utama dari manajemen pembangunan. Dengan perencanaan pembangunan yang baik, kegiatan pembangunan dapat dirumuskan secara efisien dan efektif dengan hasil yang optimal. Dengan demikian, perencanaan merupakan bagian terpenting dalam kegiatan pembangunan yang dilakukan oleh pemerintah. Bahkan pemerintah melalui UU No. 25 Tahun 2004 Tentang Sistem Perencanaan Pembangunan Nasional (SPPN) memberikan jaminan bahwa perencanaan pembangunan disusun agar kegiatan pembangunan berjalan efektif, efisien, dan bersasaran.

Berbagai pengertian telah diberikan terhadap istilah perencanaan pembangunan. Menurut UU No 25 Tahun 2004 Tentang Sistem Perencanaan Pembangunan Nasional dan juga PP No. 8 Tahun 2008 tentang Tata Cara Penyusunan, Pengendalian dan Evaluasi Pelaksanaan Perencanaan Pembangunan, menyebutkan perencanaan adalah suatu proses untuk menentukan tindakan masa depan yang tepat, melalui urutan pilihan, dengan memperhitungkan sumber daya yang tersedia. 
Sedangkan Perencanaan Pembangunan Daerah merupakan suatu proses penyusunan tahapantahapan kegiatan yang melibatkan berbagai unsur pemangku kepentingan didalamnya, guna pemanfaatan dan pengalokasian sumber daya yang ada dalam rangka meningkatkan kesejahteraan sosial dalam suatu lingkungan wilayah/daerah dalam jangka waktu tertentu.

Riyadi dan Deddy Supriady B. $(2005: 7)$ mengartikan perencanaan pembangunan sebagai suatu proses perumusan alternatifalternatif atau keputusan-keputusan yang didasarkan pada data-data dan fakta-fakta yang akan digunakan sebagai bahan untuk melaksanakan suatu rangkaian kegiatan/aktivitas kemasyarakatan, baik yang bersifat fisik (material) maupun nonfisik (mental spiritual), dalam rangka mencapai tujuan yang lebih baik. Kemudian untuk konteks daerah, perencanaan pembangunan daerah diartikan sebagai suatu proses perencanaan pembangunan yang dimaksudkan untuk melakukan perubahan menuju arah perkembangan yang lebih baik bagi suatu komunitas masyarakat, pemerintah dan lingkungannya dalam wilayah tertentu, dengan $\mathrm{m}$ e $\mathrm{m}$ a $\mathrm{n} \mathrm{fa} \mathrm{a} \mathrm{t} \mathrm{k} \mathrm{a} \mathrm{n} \mathrm{a} \mathrm{ta} u$ mendayagunakan berbagai sumber daya yang ada, dan harus memiliki orientasi yang bersifat menyeluruh, lengkap, tapi tetap berpegang pada azas prioritas.

Ginanjar Kartasasmita (1997) mengartikan perencanaan pembangunan daerah sebagai instrumen bagi penentuan alokasi sumber daya pembangunan dan lokasi kegiatan di daerah yang telah direncanakan terpusat yang berguna untuk mencegah terjadinya kesenjangan ekonomi antar daerah (Bratakusumah dan Riyadi, 2005:43). Sedangkan Siagiaan mengartikan perencanaan adalah keseluruhan proses pemikiran dan penentuan secara matang menyangkut hal-hal yang akan dikerjakan di masa datang dalam rangka mencapai tujuan yang telah ditentukan sebelumnya.

Dan secara sederhana, Indra Bastian (2006) mengartikan bahwa perencanaan pembangunan daerah sebagai sebuah proses pengambilan keputusan mengenai kebijakan dan program pembangunan daerah oleh Pemerintah Provinsi atau Pemerintah Kabupaten/ Kota yang dilakukan secara terpadu yang bertujuan untuk meningkatkan kesejahteraan masyarakat di daerah yang bersangkutan dengan $\mathrm{m}$ e $\mathrm{m}$ a $\mathrm{n}$ f a a t k a $\mathrm{d}$ a $\mathrm{n}$ memperhitungkan kemampuan sumber daya, informasi, ilmu pengetahuan dan teknologi, serta memperhatikan perkembangan dunia global. Perencanaan pembangunan juga memikul tanggung jawab pelaksanaan fungsi manajemen pemerintahan dan pembangunan, dari penyiapan kebijakan sampai dengan pertanggungjawaban kinerja kebijakan-kebijakan pembangunan yang ditetapkan (Mustopadidjaja AR, 2009). 


\section{Evaluasi Dampak Perencanaan Pembangunan}

Ukuran dampak dari perencanaan pembangunan daerah dapat diketahui dengan memperhatikan kinerja ekonomi daerah yang bersangkutan, melalui tinjauan indikator ekonomi dan indikator sosial. Hal ini sejalan dengan PP No. 8 Tahun 2008 Tentang Tahapan, Tata Cara Penyusunan, Pengendalian, dan Evaluasi Pelaksanaan Rencana Pembangunan Daerah yang menyebutkan bahwa proses penyelenggaraan perencanaan harus dapat memberikan arahan bagi peningkatan pengembangan sosial-ekonomi dan kemampuan masyarakat. Dengan demikian suatu perencanaan pembangunan daerah dikatakan berhasil apabila output dan outcome-nya memiliki dampak pada pertumbuhan sosial dan ekonomi masyarakatnya.

Menurut Siagian dalam bukunya Filsafat Administrasi menyebutkan bahwa evaluasi (penilaian) didefinisikan sebagai proses pengukuran dan pembandingan dari hasil-hasil pekerjaan yang nyatanya dicapai dengan hasil-hasil yang seharusnya dicapai. Sementara itu tujuan evaluasi adalah untuk menilai secara keseluruhan pengaruh dan dampak pada akhir program, yang akan menjadi landasan untuk $\mathrm{m}$ e $\mathrm{n} \mathrm{i} \mathrm{g} \mathrm{k}$ a t $\mathrm{k}$ a $\mathrm{n}$ a $\mathrm{ta} u$ menyempurnakan kebijakan berkenaan dengan program selanjutnya. Namun secara konseptual ada pandangan yang menyatakan bahwa evaluasi dapat dilakukan pada seluruh periode kegiatan, karenanya evaluasi dapat dibedakan mejadi tiga (Bratakusumah dan Riyadi, 2005) yaitu:

1. Pra evaluasi

Evaluasi yang dilakukan pada s a a t program belum berjalan/beroperasi pada tahap perencanaan. Evaluasi difokuskan pada persiapan suatu kegiatan ataupun pada hasil pelaksanaan sebelumnya. Evaluasi pada periode ini biasanya meliputi analisis aspek keuangan dan analisis ekonomis dari suatu kegiatan (cost and benefits analysis).

2. Evaluasi pada saat program tengah berjalan

Dikenal dengan on-going evaluation atau in-operation evaluation. Evaluasi pada tahap ini difokuskan pada penilaian dari setiap tahap kegiatan yang sudah dilaksanakan, walaupun belum bisa dilakukan penilaian terhadap keseluruhan proses program. Pada saat program tengah berjalan analisis evaluasi bersumber pada hasil pemantauan yang dilaksanakan terhadap tahapan-tahapan kegiatan secara berkelanjutan dan akan memberi umpan balik untuk perencana dan pelaksana pembangunan.

3. Evaluasi setelah program selesai atau setelah program berakhir. Evaluasi ini disebut post evaluation atau evaluasi pascaprogram. Pada evaluasi ini dilakukan penilaian terhadap seluruh tahapan program yang 
dikaitkan dengan tingkat keberhasilannya, sesuai dengan indikator yang ditetapkan dalam rumusan sasaran atau tujuan program. Pada saat berakhirnya implementasi, analisis evaluasi lebih ditekankan pada dampak program, khususnya dampak ekonomi dan sosial terhadap kelompok sasaran dan masyarakat sekitarnya.

Dadang Solihin (2008) membedakan evaluasi menurut waktu pelaksanaannya menjadi 2 (dua), yaitu:

1. Evaluasi formatif, yaitu evaluasi yang dilaksanakan pada waktu pelaksanaan program dan bertujuan untuk memperbaiki pelaksanaan program. Temuan utamanya berupa masalahmasalah dalam pelaksanaan program;

2. Evaluasi summatif, yaitu evaluasi yang dilaksanakan pada saat pelaksanaan program sudah selesai dan bertujuan untuk menilai hasil pelaksanaan program. Temuan utamanya berupa capaian-capaian dari pelaksanaan program.

Sedangkan menurut tujuannya, maka evaluasi dapat dibedakan menjadi tiga, yaitu:

1. Evaluasi proses, yaitu evaluasi dilakukan untuk mengkaji bagaimana program berjalan dengan fokus pada masalah penyampaian pelayanan (service delivery);
2. Evaluasi biaya-manfaat, yaitu evaluasi yang dilakukan untuk mengkaji biaya program relatif terhadap alternatif penggunaan sumberdaya \& manfaat dari program;

3. Evaluasi dampak, yaitu evaluasi yang dilakukan untuk mengkaji apakah program memberikan pengaruh yang diinginkan terhadap individu, rumah tangga, masyarakat, dan kelembagaan.

Evaluasi untuk pelaksanaan sebuah rencana adalah bagian dari kegiatan perencanaan pembangunan yang secara sistematis mengumpulkan dan menganalisis data dan informasi untuk menilai pencapaian sasaran, tujuan dan kinerja pembangunan. Evaluasi ini dilaksanakan berdasarkan indikator dan sasaran kinerja yang tercantum dalam dokumen rencana pembangunan. Indikator kinerja dalam evaluasi adalah ukuran ringkas dengan menggunakan ukuran kuantitatif $\mathrm{d}$ a $\mathrm{n} \mathrm{u}$ a litatif y a $\mathrm{g}$ mengindikasikan pencapaian suatu sasaran atau tujuan yang telah disepakati atau ditetapkan. Indikator dan sasaran kinerja mencakup masukan (input), keluaran (output), hasil (outcome), dan dampak (impact) (Modul SAKIPLAN, 2003).

Masukan (input) adalah segala sesuatu yang dibutuhkan agar kegiatan dan program dapat berjalan atau dalam rangka 
memberikan kontribusi dalam menghasilkan output. Input diantaranya adalah anggaran (dana), SDM, peralatan, material, dan masukan lainnya yang dipergunakan untuk kegiatan melaksanakan kegiatan. Dengan melihat distribusi sumberdaya sebagai input dapat dianalisis apakah alokasi sumberdaya yang dimiliki telah sesuai dengan rencana stratejik yang ditetapkan atau tidak. Ketepatan dalam mengalokasikan atau mendistribusikan sumberdaya akan sangat berpengaruh terhadap hasil yang dicapai.

Keluaran (output) adalah produk barang atau jasa yang secara langsung dihasilkan dari pelaksanaan suatu kegiatan dan program berdasarkan masukan yang digunakan. Output biasanya dijadikan landasan untuk menilai keberhasilan suatu kegiatan dan program apabila dikaitkan dengan sasaran kegiatan yang terdefinisi dengan baik dan terukur. Jika output dari kegiatan dan program telah sesuai dengan yang diharapkan, maka kegiatan dan program tersebut bisa dikatakan telah berjalan dengan baik.

Hasil (outcome) adalah sesuatu yg mencerminkan berfungsinya keluaran atau output. Indikator outcome sebenarnya lebih baik dibandingkan dengan output dalam hal menjelaskan keberhasilan dari sebuah kegiatan. Walaupun barang dan jasa yang dihasilkan oleh kegiatan telah berhasil dicapai, namun belum tentu secara outcome kegiatan tersebut telah berhasil. Outcome menggambarkan tingkat pencapaian atas hasil yang lebih tinggi yang mungkin menyangkut kepentingan banyak pihak. Outcome merupakan ukuran yang dapat digunakan oleh instansi untuk mengetahui seberapa jauh output dapat dipergunakan sebagaimana mestinya dan memberikan kegunaan yang besar bagi masyarakat.

Dampak (impact) adalah hasil pembangunan yang diperoleh dari outcome atau ukuran tingkat pengaruh secara makro dari sisi sosial, ekonomi, lingkungan atau kepentingan umum lainnya yang dimulai oleh capaian kinerja setiap indikator dalam suatu kegiatan. Impact merupakan perubahan positif maupun negatif yang dihasilkan oleh sebuah intervensi pembangunan, baik secara langsung maupun tidak dan disengaja atau tidak. Indikator impact memperlihatkan pengaruh yang ditimbulkan dari manfaat yang diperoleh dari hasil kegiatan. Indikator ini baru dapat diketahui dalam jangka waktu menengah dan panjang. Indikator dampak menunjukkan dasar pemikiran mengapa kegiatan dilaksanakan, dan menggambarkan aspek makro pelaksanaan kegiatan, tujuan kegiatan secara sektoral, regional dan nasional.

Selama ini seringkali evaluasi hanya dilakukan dan berfokus pada masukan (input), dan keluaran (output), sedangkan hasil (outcome) dan dampak (impact) kurang 
diperhatikan. Sehingga pemerintah sebagai organisasi sektor publik tidak akan mampu melihat keberadaannya sendiri bahwa ia ada untuk melayani masyarakat. Pengukuran outcome di sektor publik adalah mengukur dampak atas aktivitas atau pelayanan yang diberikan oleh organisasi sektor publik terhadap masyarakat. Sementara impact merupakan konsekuensi lanjutan dari outcome, sehingga outcome dan impact adalah suatu kesatuan (Mahmudi, 2005).

Evaluasi dampak (impact evaluation) sebenarnya tidak jauh berbeda dengan evaluasi yang telah ada, yang membedakan hanyalah evaluasi dampak lebih menitikberatkan pada outcome dan impact. Istilah "impact" secara harfiah dimaksudkan sebagai akibat jangka panjang baik itu dampak positif maupun negatif, yang diharapkan ataupun tidak diharapkan.

Menurut Development Assistance Committee (DAC), pelaksanaan evaluasi yang baik seharusnya fokus pada lima kriteria, termasuk impact atau dampak itu sendiri (Peter Ellis, 2006). Adapun lima kriteria tersebut adalah :

1. Relevance (were the objectives right?);

2. Effectiveness (how well were the objectives achieved?);

3. Efficiency (was it value for money?);

4. Impact;

5. Sustainability (will benefits, particularly in systems or institutions, be sustained?).

Relevansi (relevance) adalah kriteria evaluasi perencanaan pembangunan yang dimaksudkan untuk melihat sejauh mana kegiatan dalam pembangunan sejalan dengan prioritas dan kebijakan yang telah dibuat (Dadang Solihin, $2008)$. Ketika kegiatan pembangunan yang dilakukan sesuai dengan perencanaan yang telah dibuat maka pelaksanaan perencanaan pembangunan tersebut telah relevan. Sebaliknya, jika kegiatan pembangunan yang dilakukan tidak sesuai atau bahkan bertentangan dengan perencanaan yang telah dibuat maka pelaksanaan perencanaan pembangunan tersebut tidak relevan.

Efektifitas (effectiveness) adalah kriteria evaluasi perencanaan pembangunan yang dimaksudkan untuk mengukur sejauh mana sebuah kegiatan dalam pembangunan untuk mencapai tujuan yang telah ditentukan (Dadang Solihin, 2008). Ketika kegiatan yang dilakukan sesuai dengan yang direncanakan dan memiliki nilai yang signifikan dalam mencapai tujuan, maka pelaksanaan perencanaan pembangunan bisa dikatakan telah berjalan efektif. Sebaliknya jika kegiatan yang dilakukan tidak memiliki nilai yang signifikan terhadap pencapaian tujuan yang telah ditentukan maka pelaksanaan perencanaan pembangunan tersebut tidak efektif. 
Dampak (impact) adalah kriteria evaluasi perencanaan pembangunan yang dimaksudkan untuk melihat perubahan positif atau negatif yang dihasilkan oleh sebuah intervensi pembangunan, secara langsung maupun tidak, dan disengaja maupun tidak (Dadang Solihin, 2008). Kriteria ini digunakan untuk melihat apakah kegiatan pembangunan yang dilakukan membawa perubahan yang positif atau negatif. Adapun indikator yang umumnya digunakan untuk melihat perubahan akibat pembangunan ada tiga, yaitu indikator ekonomi, sosial, dan lingkungan. Ketika ketiga indikator tersebut menunjukkan perubahan yang positif maka perencanaan pembangunan dan pembangunan memberikan dampak yang positif. Sebaliknya, ketika menunjukkan perubahan yang negatif maka dapat dikatakan bahwa perencanaan pembangunan dan pembangunan yang telah dilakukan memberikan dampak yang negatif. Lebih jauh adalah bahwa sebuah perencanaan pembangunan bisa disebut efektif apabila pencapaian target, tujuan dan sasaran pembangunan yang telah ditetapkan bisa terwujud.

Sedangkan berkelanjutan (sustainability) adalah kriteria evaluasi perencanaan pembangunan yang dimaksudkan untuk mengukur apakah manfaat suatu kegiatan dapat terus dinikmati setelah anggaran tidak diberikan lagi (Dadang Solihin, 2008). Dengan kata lain, apakah output dari kegiatan pembangunan tersebut kedepan dapat berjalan dengan sendirinya meskipun tanpa ada intervensi dari pemerintah. Setiap output dari kegiatan pembangunan yang tetap ada dan berfungsi sebagaimana mestinya menunjukkan nilai keberlanjutan.

\section{HASIL DAN PEMBAHASAN}

\section{Aspek Ekonomi}

Berdasarkan perbandingan data angka pertumbuhan ekonomi di setiap daerah dalam beberapa tahun dari 2006 hingga 2008 maka bisa terlihat bahwa pertumbuhan ekonomi di beberapa daerah cenderung meningkat, sedangkan di beberapa daerah lain justru mengalami penurunan. Daerah yang mengalami penurunan pertumbuhan ekonomi yaitu Kabupaten Berau, Sanggau, dan Bengkayang. Ini menjadi kontradiktif dengan upaya peningkatan kesejahteraan masyarakat, karena pertumbuhan ekonomi yang menurun merupakan penurunan kinerja ekonomi daerah.

Sedangkan di beberapa kabupaten yang mengalami kenaikan pertumbuhan ekonomi, artinya secara makro dalam level kabupaten terjadi perkembangan ekonomi menjadi lebih baik dari tahun ke tahun, meskipun dengan tingkat pertumbuhan yang bervariasi. Ada 3 (tiga) kabupaten yang menunjukkan peningkatan pertumbuhan ekonomi setiap tahunnya, yaitu Kabupaten Kutai Barat, Kotabaru, dan Kotawaringin Timur. 


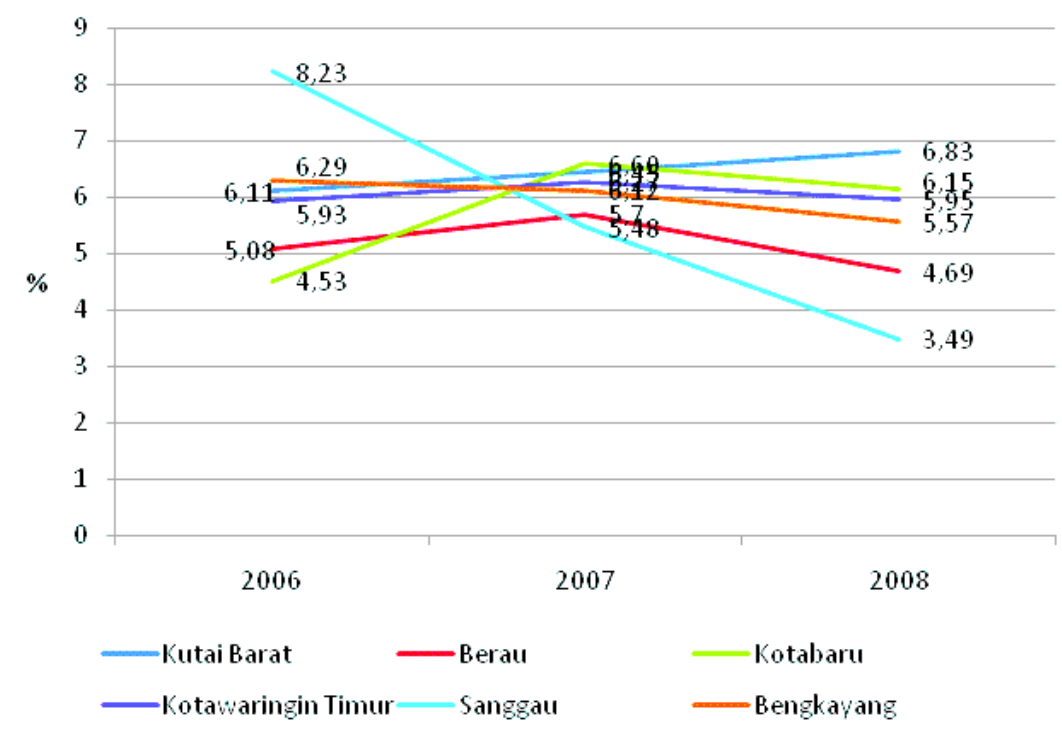

Sumber: Dari Berbagai Sumber, diolah

Gambar 4.1

Pertumbuhan Ekonomi Beberapa Kabupaten di Kalimantan Tahun 2006-2008

Bervariasinya pertumbuhan ekonomi di setiap kabupaten ini sangat dipengaruhi oleh pertumbuhan dan kontribusi setiap sektor terhadap PDRB. Ketika sektor yang dominan dalam PDRB mengalami pertumbuhan atau perlambatan pertumbuhan, maka pertumbuhan PDRB secara total akan sangat terpengaruh. Sebagai contoh, sektor pertambangan di Kabupaten Kutai Barat yang mendominasi perekonomian daerah tersebut. Ketika sektor pertambangan tumbuh dan sektor lain cenderung tetap atau turun, secara total perekonomian Kabupaten Kutai Barat akan tetap tumbuh.

Selain itu, secara umum kinerja ekonomi kabupaten- kabupaten di Kalimantan masih didominasi oleh sektor primer atau sektor sumber daya alam yaitu sektor pertanian dan pertambangan. Perekonomian Kabupaten Kutai Barat dan Berau di Kalimantan Timur cenderung didominasi oleh sektor pertambangan, dimana kontribusinya yang signifikan terhadap pendapatan daerah. Sifat sumber daya alam dari sektor pertambangan yang tidak bisa diperbarui menjadikan pemerintah daerah harus bisa mencari alternatif sumber pendapatan lain di luar sektor pertambangan. Dan ini sesuai dengan visi kedua daerah tersebut yang memiliki kecenderungan untuk mempersiapkan sektor pertanian sebagai lokomotif baru bagi perekonomian mereka di masa yang akan datang. Sedangkan 
perekonomian kabupaten lainnya di Kalimantan Selatan, Kalimantan Tengah, dan Kalimantan Barat cenderung didominasi oleh sektor pertanian. Sektor pertanian menjadi kunggulan di daerah tersebut karena, sektor-sektor lain masih belum mampu berkontribusi secara signifikan terhadap perekonomian daerah.

Masuknya sektor pertanian dalam arti luas sebagai salah satu sektor unggulan di beberapa kabupaten merupakan kondisi yang baik, mengingat sektor pertanian saat ini menjadi primadona seiring dengan program pemerintah yang ingin mengembangkan perkebunan kelapa sawit. Selain itu sektor pertanian adalah sektor ekonomi yang terbarukan, sehingga dapat dijadikan andalan dalam mendukung perekonomian daerah di masa yang akan datang selain sektor-sektor potensial lainnya.

Untuk melihat pertumbuhan tingkat kesejahteraan masyarakat, sedikit banyak pertumbuhan ekonomi dapat menggambarkan hal tersebut. Namun karena dalam nilai PDRB masih terdapat komponenkomponen yang tidak dapat dinikmati oleh masyarakat secara Iangsung seperti penyusutan, pajak tak langsung neto, dan faktor pendapatan neto (net factor income), maka penggunaan PDRB per kapita dinilai lebih baik. Meskipun PDRB per kapita itu sendiri masih dianggap kurang ideal menggambarkan kesejahteraan masyarakat karena belum mempertimbangkan distribusi pendapatan yang tidak merata dan indikator lain yang relevan.

Angka PDRB perkapita diperoleh dengan membagi PDRB baik atas dasar harga berlaku maupun atas dasar harga konstan dengan jumlah penduduk. PDRB perkapita adalah rata-rata nilai tambah perkapita yang mencerminkan tingkat kesejahteraan masyarakat suatu daerah. Pertumbuhan PDRB perkapita di beberapa kabupaten di Kalimantan menunjukkan kecenderungan yang positif dan meningkat, meskipun ada fluktuasi. Hanya ada satu kabupaten yang pertumbuhan PDRB perkapitanya melambat, yaitu Kabupaten Sanggau. Pertumbuhan PDRB perkapita Kabupaten Sanggau pada tahun 2008 tercatat 1,74 persen, melambat dari dua tahun sebelumnya yang mencapai 6,77 persen. Perlambatan pertumbuhan ini dipengaruhi oleh pertumbuhan PDRB yang melambat, yang juga dipengaruhi oleh perlambatan pertumbuhan sektor dan sub sektor dalam PDRB Kabupaten Sanggau. 


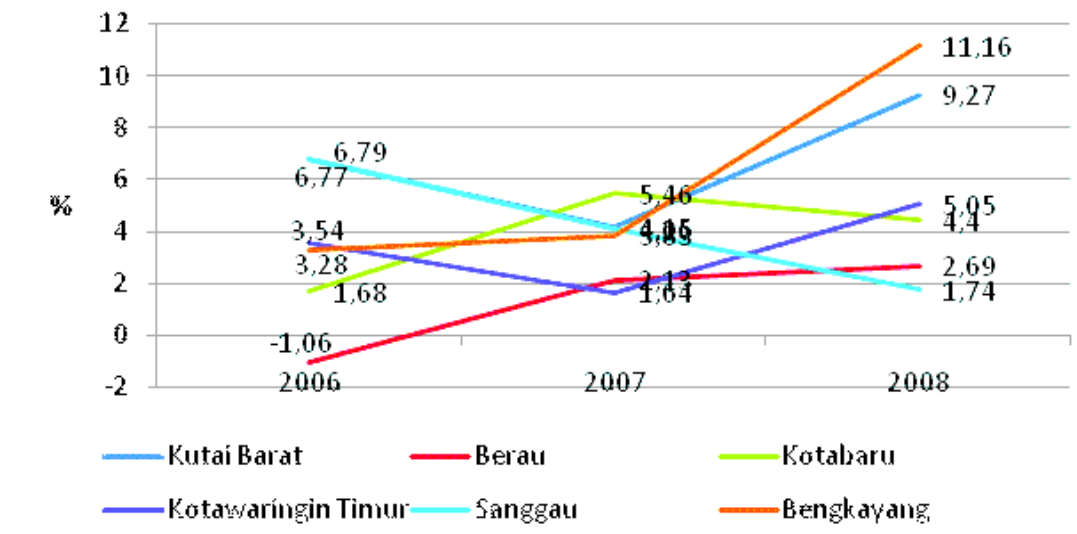

Sumber: Dari Berbagai Sumber, diolah

Gambar 4.2

Pertumbuhan PDRB Per Kapita Beberapa Kabupaten di Kalimantan

Terkecuali Kabupaten Sanggau, pertumbuhan PDRB per kapita kabupaten lainnya cenderung meningkat. Pertumbuhan yang tinggi dicapai oleh Kabupaten Bengkayang. Pada tahun 2008 pertumbuhan PDRB per kapita di Kabupaten Bengkayang mencapai 11,16 persen, padahal dua tahun sebelumnya pertumbuhannya hanya sekitar 3 persen. Pada tahun 2008, pertumbuhan PDRB Per Kapita Kabupaten Kutai Barat meningkat 9,27 persen, Kabupaten Kotawaringin Timur meningkat 5,05 persen, Kabupaten Kotabaru meningkat 4,4 persen, dan Kabupaten Berau yang meningkat 2,69 persen. Pertumbuhan PDRB Per Kapita yang cenderung meningkat di beberapa kabupaten, menunjukkan keberhasilan pemerintah daerah setempat dalam meningkatkan kesejahteraan penduduk melalui pembangunan ekonomi.

\section{Aspek Sosial}

Indeks Pembangunan Manusia (IPM) merupakan paramater pembangunan di bidang SDM dimana manusia ditempatkan sebagai sasaran pembangunan, human centered developmnet. Ini merupakan instrumen baru yang awalnya dikembangkan oleh seorang ekonom Pakistan, Mahbub Ul Haq, untuk menilai seberapa besar keberhasilan pemerintah dalam memberdayakan manusia sebagai pusat pembangunan. Pola ini kemudian digunakan UNDP sebagai instrumen untk menilai pembangunan manusia, ini sekaligus merupakan upaya untuk menggeser fokus pembangunan dari ekonomi semata kepada pembangunan yang berpusat pada manusia.

I PM pada dasarnya menggabungkan tiga dimensi yaitu kesehatan, pendidikan dan ekonomi sebagai komponen untuk 
menghasilkan angka IPM. Dimensi kesehatan menggunakan angka harapan hidup pada waktu lahir sebagai indeks kesehatan dan lamanya hidup masyarakat. Dimensi pendidikan menggunakan angka melek huruf rata-rata orang dewasa dengan partisipasi sekolah pada sekolah dasar, menengah dan atas. Kemudian dari dimensi ekonomi menggunakan PDB perkapita pada paritas daya beli (purchasing power parity). Angka IPM yang semakin tinggi mencerminkan kualitas pembangunan manusia yang semakin baik, sebaliknya IPM yang rendah mencerminkan kualitas pembangunan manusia yang semakin buruk.

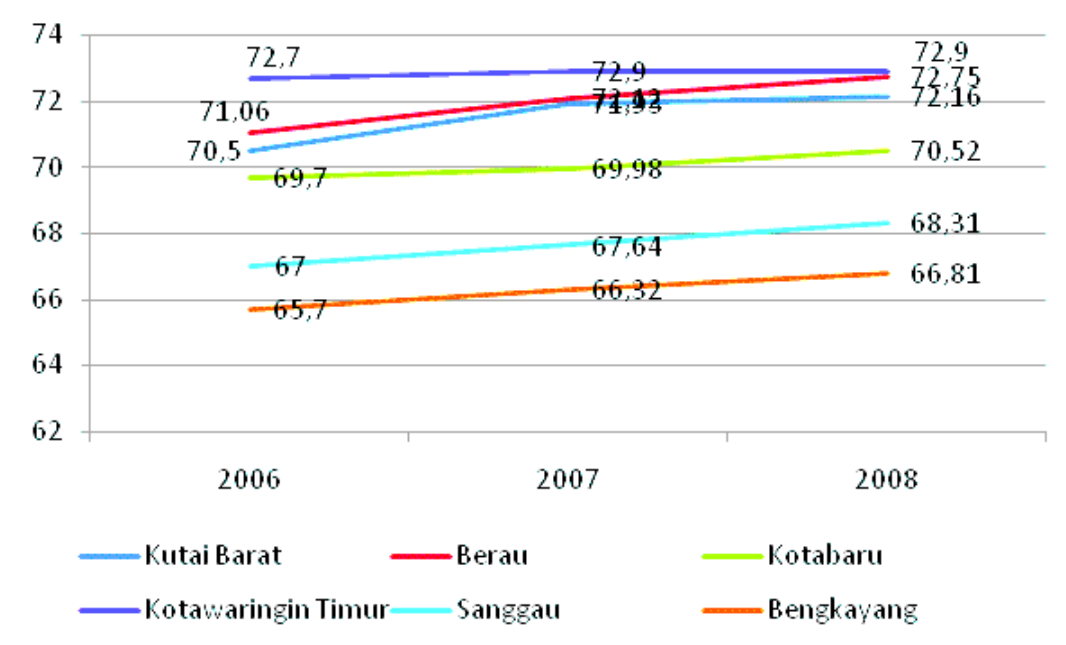

Sumber: Dari Berbagai Sumber, diolah

Gambar 4.3

Indeks Pembangunan Manusia (IPM) Beberapa Kabupaten di Kalimantan

Angka IPM di beberapa kabupaten di Kalimantan dari tahun 2006 hingga 2008 mengalami perkembangan secara positif dimana terjadi peningkatan secara terus menerus kecuali Kabupaten Kotawaringin Timur yang mengalami stagnasi pada tahun 2008. Peningkatan IPM tertinggi selama tiga tahun tersebut dicapai oleh Kabupaten Berau, yang meningkat 1,69 poin, kemudian Kabupaten Kutai Barat, yang meningkat 1,66 poin. Sedangkan peningkatan IPM terendah dalam waktu yang sama adalah Kabupaten Kotawaringin Timur, yang meningkat 0,2 poin. Meskipun peningkatan IPM Kabupaten Kotawaringin Timur terendah, namun IPM kabupaten tersebut pada tahun $2008(72,9)$ merupakan IPM tertinggi diantara kabupatenkabupaten yang menjadi sampel kajian. IPM kabupaten lainnya adalah Kabupaten Berau (72,75), Kabupaten Kutai Barat $(72,16)$, Kabupaten Kotabaru (70,52), 
Kabupaten Sanggau $(68,31)$, dan yang terendah Kabupaten Bengkayang $(66,81)$.

IPM beberapa kabupaten yang menjadi sampel dalam kajian ini secara umum menjelaskan kualitas sumberdaya manusia di beberapa kabupaten tersebut relatif cukup baik, karena IPM nasional sendiri hanya 71,17. Meskipun pembangunan sumberdaya manusia di beberapa kabupaten tersebut sudah terhitung baik, namun masih dipandang perlu untuk menempuh langkah-langkah akselerasi guna mencapai tingkat HDI/IPM ideal menurut UNDP atau Bank Dunia yakni pada skor 80 . Selain itu The IMD World Competitiveness Yearbook 2009 baru-baru ini menempatkan Indonesia pada rangking 42 dari 57 negara di dunia dalam hal daya saing, termasuk didalamnya adalah daya saing sumberdaya manusia. Posisi ini lebih rendah dari negara tetangga singapura (2), Malaysia (18) dan Thailand (26).

Selain IPM sebagai indikator kualitas sumberdaya manusia, tingkat kemiskinan dapat dijadikan indikator lain dari aspek sosial untuk menilai hasil pembangunan daerah. Kemiskinan merupakan permasalahan dalam pembangunan yang harus dihadapi oleh seluruh daerah, baik yang sudah maju maupun yang belum maju. Masyarakat miskin umumnya lemah dalam kemampuan berusaha dan terbatas dalam akses sarana dan prasarana, modal dan kegiatan sosial ekonomi lainnya, sehingga tertinggal jauh dari masyarakat yang memiliki potensi yang lebih tinggi. Kondisi seperti ini umumnya akan memunculkan permasalahanpermasalahan baru, yang diantaranya adalah tingginya tingkat kriminalitas, dekadensi moral dan etika, produktivitas dan kreatifitas yang rendah dan permasalahan sosial lainnya akibat beratnya beban ekonomi masyarakat. Selain itu kemiskinan akan menghambat pembangunan wilayah, pemerataan pembangunan dan demokrasi ekonomi. Oleh karena itu pengentasan kemiskinan perlu dijadikan prioritas utama dalam pembangunan suatu daerah.

Kemiskinan adalah masalah yang kompleks, yang penanggulangannya pun tidak mudah. Namun demikian, bukan berarti hal ini bisa dijadikan alasan pembenaran pemerintah dari kegagalannya menanggulangi kemiskinan. Kemiskinan tidak hanya disebabkan atau dipengaruhi oleh terbatasnya pendapatan dan akses masyarakat terhadap sumbersumber ekonomi, tetapi juga bisa dipengaruhi tingkat pendidikan dan kesehatan. Sehingga peran pemerintah tidak hanya berusaha bagaimana agar masyarakat dapat meningkatkan pendapatannya, tetapi meningkatkan akses masyarakat terhadap sumbersumber ekonomi, dan meringankan beban mereka khususnya di bidang pendidikan dan kesehatan. Orang yang memiliki tingkat pendidikan yang rendah akan sulit maju dan berkembang, sehingga dapat mengurangi kesempatan seseorang 
untuk keluar dari kemiskinan. Demikian juga dengan tingkat kesehatan yang rendah, akan berakibat pada sumber daya manusia yang tidak sehat dan tidak produktif.

Kondisi kemiskinan di beberapa kabupaten yang menjadi sampel dalam kajian ini menunjukkan kondisi yang cukup menggembirakan. Tingkat kemiskinan di beberapa kabupaten menunjukkan penurunan, dengan tingkat penurunan yang bervariasi antar daerah. Penurunan tingkat kemiskinan tercepat dialami oleh Kabupaten Bengkayang yang menurun dari 14,63 persen pada tahun 2006 menjadi 9,41 persen pada tahun 2008. Penurunan tingkat kemiskinan di beberapa kabupaten ini menunjukkan bahwa kesejahteraan masyarakat di kabupaten tersebut cenderung meningkat. Secara tidak langsung hal ini menunjukkan keberhasilan pemerintah daerah dalam meningkatkan taraf hidup warganya melalui kebijakan-kebijakan yang telah dilakukan.

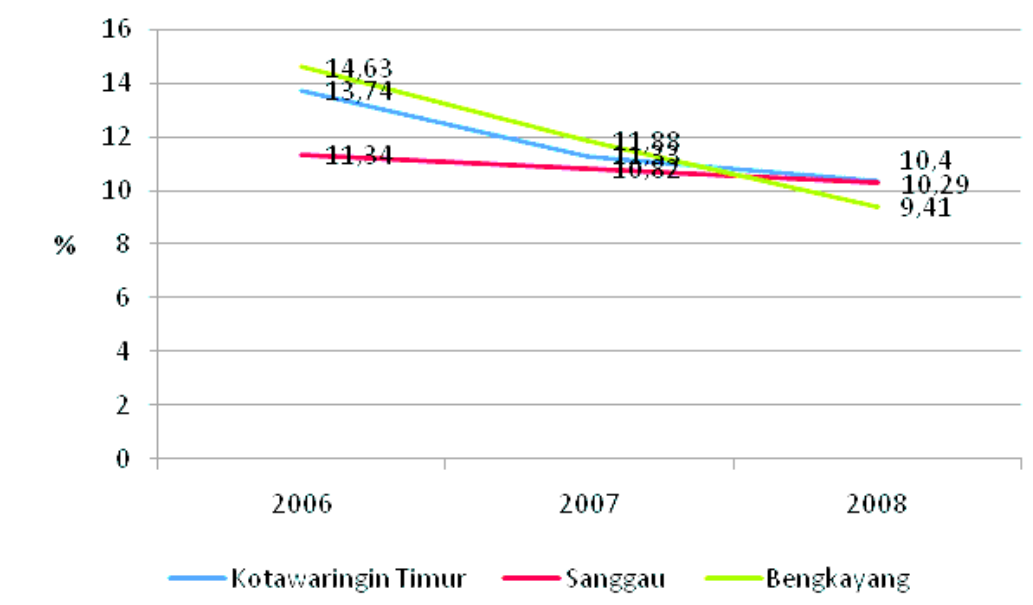

Sumber: Dari Berbagai Sumber, diolah

\section{Gambar 4.4}

Tingkat Kemiskinan di Beberapa Kabupaten di Kalimantan

Tahun 2006-2008

Persoalan kemiskinan bukan hanya sekadar berapa jumlah dan persentase penduduk miskin. Dimensi lain yang perlu diperhatikan adalah tingkat kedalaman dan keparahan kemiskinan. Selain itu, selama ini garis kemiskinan yang ditetapkan oleh pemerintah dirasa masih terlalu rendah sehingga masih banyak warga yang sebenarnya miskin tetapi dimasukkan dalam golongan tidak miskin. Jika menggunakan standar garis kemiskinan versi Bank Dunia, yaitu US\$ 2 per hari, dapat dipastikan tingkat kemiskinan di 
kabupaten tersebut akan semakin tinggi. Oleh karena itu perlu ada usaha yang lebih keras lagi bagi pemerintah daerah untuk menangani kemiskinan di daerahnya masing-masing.

Selain kualitas sumberdaya manusia dan tingkat kemiskinan, tingkat pengangguran juga dapat digunakan sebagai indikator dari aspek sosial untuk menilai hasil pembangunan daerah. Tingginya tingkat pengangguran berpotensi m e n imbulkan berbaga i permasalahaan sosial. Oleh karena itu beberapa Pemerintah Daerah menempatkan penciptaan kesempatan kerja sebagai salah satu s a s a ran pokok d a la m pembangunan. Untuk menurunkan tingkat pengangguran, pemerintah dituntut untuk mampu menciptakan lapangan pekerjaan baru. Pembangunan perekonomian melalui investasi sebenarnya dapat mengurangi tingkat pengangguran, namun tidak semua angkatan kerja yang ada dapat terserap ke lapangan kerja yang tersedia, maka timbulah pengangguran. Pengangguran sendiri terjadi akibat laju investasi untuk penciptaan lapangan kerja lebih lambat dari pada perkembangan angkatan kerja sehingga kesempatan kerja menjadi sangat terbatas.

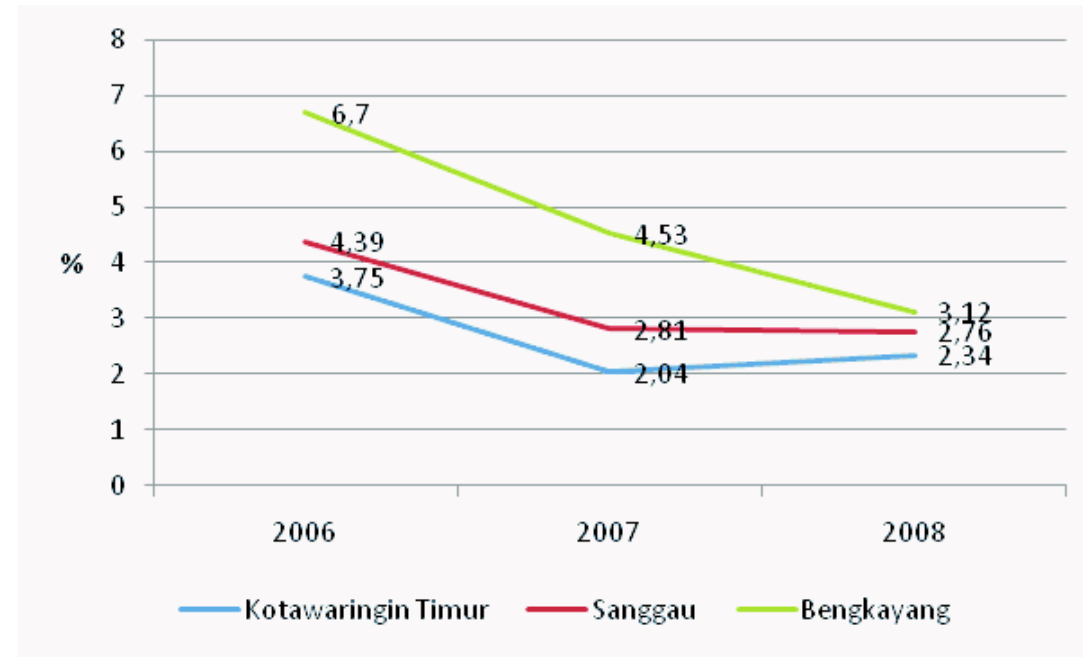

Sumber: Dari Berbagai Sumber, diolah

\section{Gambar 4.5}

Tingkat Pengangguran di Beberapa Kabupaten di Kalimantan

Tahun 2006-2008

Tingkat pengangguran di beberapa kabupaten yang menjadi sampel dalam kajian ini menunjukkan tren yang semakin baik, walaupun kondisi akhirnya belum mencerminkan hasil yang diharapkan. Dalam kurun waktu tiga tahun, dari tahun 2006 hingga 
tahun 2008, tingkat pengangguran semakin menurun. Penurunan tingkat pengangguran ini menunjukkan penambahan angkatan kerja telah diimbangi dengan pembukaan lapangan pekerjaan baru. Kecuali Kabupaten Kota waringin Timur dimana pada tahun 2008 justru terjadi kenaikan jumlah pengangguran sekitar $0,3 \%$. Hal ini menunjukkan bahwa akses dan kesempatan kerja bagi masyarakat di daerah tersebut sangat sulit.

\section{Aspek Lingkungan}

Pembangunan pada dasarnya adalah untuk kesejahteraan manusia. Untuk itu pembangunan daerah harus memperhatikan kemanfaatan bagi masyarakat dengan tidak mengabaikan faktor kelestarian li ng kungan s e hing ga keseimbangan lingkungan dapat t e r jaga. S a y a n gny a, pertumbuhan perekonomian selama ini biasanya diiringi dengan penurunan kualitas lingkungan, khususnya perekonomian yang tergantung $\mathrm{p}$ a d a s e k t or y a $\mathrm{ng}$ mengeksploitasi sumberdaya alam seperti pertambangan. Ketergantungan ekonomi pada sektor pertambangan membawa konsekuensi kepada kerusakan lingkungan. Hal ini karena cara penambangan yang dilakukan secara terbuka akan merusak berbagai kekayaan hayati di atasnya.
Upaya menyelenggarakan pengendalian dampak pembangunan terhadap lingkungan sebenarnya telah dilakukan oleh semua pemerintahan daerah, diantaranya ditunjukkan dengan adanya institusi pemerintah daerah yang mengurusi lingkungan hidup. Selain itu, hampir semua kabupaten yang menjadi sampel dalam kajian ini menyatakan pentingnya kelestarian lingkungan hidup dalam RPJMD mereka. Namun tidak dapat dipungkiri, seiring dengan upaya untuk meningkatnya aktivitas perekonomian, kualitas lingkungan akan menurun.

Terkait dengan hal ini maka sesuai UU No. 32 Tahun 2009 mengenai perlindungan dan pengelolaan lingkungan hidup bahwa setiap kegiatan yang berdampak besar harus memiliki Amdal. Kewajiban Amdal ini kemudian diatur dengan Peraturan Menteri Negara Lingkungan Hidup No. 11 Tahun 2006 tentang Jenis Rencana Usaha/Kegiatan yang Wajib Amdal. Sebagai pelaksanaan peraturan perundangan tersebut maka setiap keputusan yang diterbitkan oleh Bupati yang berdampak besar dan penting harus selalu melalui Amdal. Diperlukan konsistensi Pemerintah Kabupaten untuk menerapkan peraturan ini sehingga pembangunan daerah tidak hanya berorientasi pada pendapatan sesaat tetapi juga memperhatikan keberlangsungan hidup jangka panjang dan kelestarian lingkungan. 
Kesadaran pemerintah daerah akan pentingnya memelihara kelestarian lingkungan masih dirasa kurang karena pembangunan lebih diarahkan kepada eksploitasi sumberdaya alam yang ada dengan kurang melihat perencanaan jangka panjang terhadap dampak lingkungan yang diakibatkan. Perekonomian selama ini belum memperhitungkan berkurangnya SDA dan rusaknya lingkungan sebagai biaya.

Beberapa contoh menurunnya kualitas lingkungan di beberapa kabupaten yang menjadi sampel kajian adalah keberadaannya hutan di Kabupaten Kotabaru baik secara kuantitas maupun kualitas telah banyak musnah dan rusak akibat aktivitas penebangan hutan. Berdasarkan data dari Dinas Kehutanan dan Perkebunan Kabupaten Kotabaru (2007), disebutkan bahwa luas lahan kritis di Kabupaten Kotabaru mencapai 100.343,5 Ha. Lahan kritis adalah lahan yang telah mengalami kerusakan sehingga kehilangan atau berkurangnya fungsi sampai batas yang ditentukan atau diharapkan. Banyaknya lahan kritis ini diduga akibat penebangan liar dan penambangan liar. Lahan kritis juga merupakan salah satu penyebab terjadinya banjir karena menyebabkan pendangkalan badan air akibat erosi aliran air dipermukaan tanah. Berdasarkan $\mathrm{s} \mathrm{u} \mathrm{m} \mathrm{b} \mathrm{e} \mathrm{r} \mathrm{d} \mathrm{a} \mathrm{r} \mathrm{i} \mathrm{D} \mathrm{i} \mathrm{n} \mathrm{a} \mathrm{s}$ Kesbanglindapmas Kabupaten Kotabaru, bencana banjir di Kabupaten Kotabaru yang cukup parah terjadi pada tahun 2006 di
Kecamatan Hampang dan Kecamatan Sampanahan dengan jumlah kerusakan berupa 47 unit rumah, $29 \mathrm{~km}$ jalan kabupaten dan 3 jembatan.

Pemerintah daerah maupun pusat sebenarnya telah melakukan beberapa upaya untuk merehabilitasi lahan dan hutan untuk memulihkan kondisi lahan dan hutan kembali normal sehingga akan mendapatkan hutan yang berkualitas, mempunyai nilai ekonomi yang tinggi, kesuburannya terjaga dan lestari. Upaya Rehabilitasi Hutan dan Lahan (RHL) yang dilakukan di kawasan hutan berupa reboisasi, rehabilitasi hutan bakau dan hutan kemasyarakatan $(\mathrm{HKm})$, sedangkan diluar kawasan hutan berupa penghijauan dan hutan rakyat. Dengan adanya kegiatan secara nasional, Gerakan Nasional Rehabilitasi Hutan dan Lahan (GNRHL) atau GERHAN yang dicanangkan sejak tahun 2003 diharapkan luasan lahan kritis semakin berkurang. Selain itu upaya lain yang telah dilakukan Pemerintah Kabupaten Kotabaru diantaranya adalah kegiatan penghijauan hutan produksi, hutan lindung dan hutan masyarakat; perlindungan sumber air Gunung Sebatung dengan luas $\pm 1,670 \mathrm{Ha}$; dan perlindungan hutan dan lahan di Desa Sembuluan, Desa Pantai Baru, Desa Gunung Ulin dan Desa Gedambaan Kecamatan Pulau Laut Utara.

Di Kabupaten Sanggau tercatat bahwa luas kawasan hutan 
mencapai 590.100 ha, yang terdiri dari 435.440 ha $(73,79 \%)$ merupakan kawasan tidak berhutan. Namun kawasan hutan yang berhutan ternyata hanya seluas 154.660 ha $(26,21 \%)$. Berdasarkan data tahun 2008 terlihat bahwa masih terdapat kawasan hutan yang rusak yakni mencapai 75.000 ha. Kondisi ini masih ditemukan di tahun 2009, dimana memang terdapat penurunan kawasan hutan yang rusak yakni hanya mencapai 33.227 ha, namun luas kawasan hutan semakin berkurang menjadi 584.936 ha. Kondisi ini menunjukkan bahwa Pemerintah Kabupaten Sanggau belum berhasil dalam mengelola lingkungan hutannya, sebab dengan semakin berkurangnya luas kawasan hutan, maka daerah-daerah resapan air akan berkurang, tanaman-tanaman yang merupakan penyedia oksigen bersih berkurang, hewan-hewan yang bergantung pada lingkungan hutan akan semakin terdegradasi, memicu terjadinya bencana banjir, longsor, juga akan menyebabkan timbulnya pemanasan global.

Permasalahan lingkungan lainnya yang dihadapi yaitu adanya pemanfaatan lahan untuk kegiatan budidaya yang tidak sesuai dengan kemampuan dan daya dukung lahannya. Misalnya pemanfaatan lahan untuk lahan perkebunan atau penggunaan lainnya pada lahan basah atau kering. Juga masih banyak terdapat kegiatan penebangan pohon melalui HPH yang berlangsung di kawasan hutan lindung. Melihat kondisi tersebut pemerintah kabupaten sanggau telah melakukan upaya reboisasi maupun penghijauan pada hutan lindung, hutan produksi, maupun hutan rakyat. Luas lahan reboisasi pada hutan lindung dan hutan produksi pada tahun 2005 mencapai 1.450 ha dan pada tahun 2007 telah dilakukan reboisasi seluas 350 ha. Adapun luas lahan penghijauan pada hutan rakyat di tahun 2005 mencapai 900 ha, dan pada tahun 2007 telah dilakukan penghijauan seluas 250 ha.

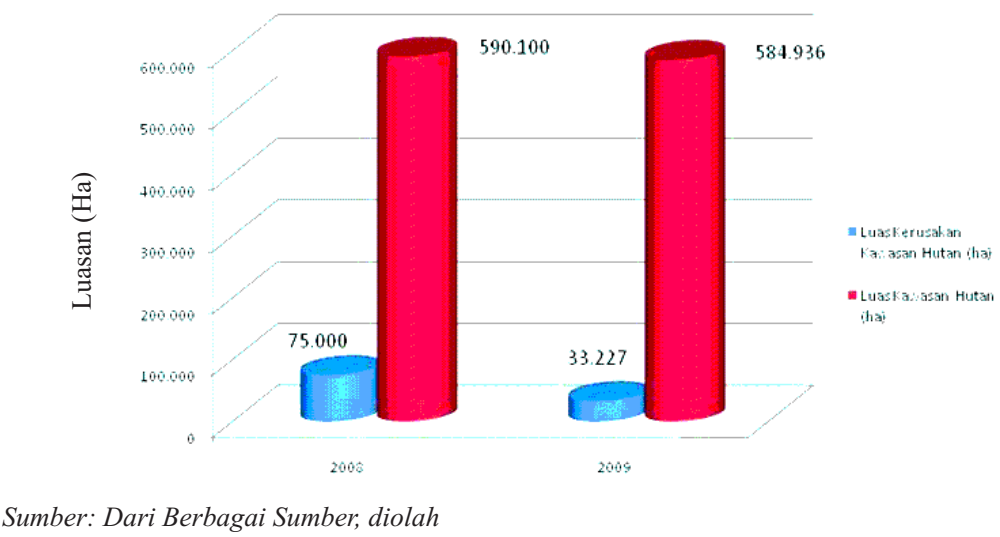

Gambar 4.6

Perbandingan Luas Kawasan Hutan dan Luas Kerusakan Kawasan Hutan di Kabupaten Sanggau Tahun 2008 - 2009 
Terdapat strategi yang ditetapkan pemerintah daerah terkait pemeliharaan kelestarian lingkungan yaitu, pengalokasian lahan bagi kawasan hutan seluas minimum $30 \%$ dari luas total wilayah kabupaten; pengalokasian Ruang Terbuka Hijau (RTH) yang berupa hutan kota, jalur hijau, taman kota, tempat rekrasi, lapangan olahraga, pemakaman umum, dan lahan pertanian pada setiap kota dengan luas minimum
$30 \%$ dari luas kota yang bersangkutan. Strategi-strategi tersebut perlu secara konsisten dilaksanakan berkesinambungan, sebab hal utama yang perlu dipahami oleh pemerintah daerah adalah meskipun pertumbuhan ekonomi merupakan prioritas pembangunan, tetapi bukan berarti harus mengorbankan kualitas lingkungan dan kesinambungan kehidupan bagi generasi mendatang.

Tabel 4.1

Potensi Rawan Banjir dan Longsor di Kabupaten Bengkayang Tahun 2010

\begin{tabular}{|c|c|c|c|c|}
\hline \multirow{2}{*}{ Uraian } & \multicolumn{2}{|c|}{ Rawan } & \multicolumn{2}{c|}{ Sangat Rawan } \\
\cline { 2 - 5 } & Ha & \% & Ha & \% \\
\hline$(1)$ & $(2)$ & $(3)$ & $(4)$ & $(5)$ \\
\hline Banjir & 82.806 & 15,2 & 17.696 & 3,2 \\
\hline Longsor & 109.474 & 20,1 & 1.266 & 0,2 \\
\hline
\end{tabular}

Sumber: Kantor Lingkungan Hidup, Kebersihan, dan Pertamanan, 2010

Kabupaten Bengkayang saat ini dikelilingi oleh 68 perusahaan, yang umumnya adalah perusahaan perkebunan. Dari sekian banyak perusahaan tersebut beberapa diantaranya sedang bermasalah, baik dengan warga maupun pemerintah. Banyaknya perusahaan perkebunan yang beroperasi di Kabupaten Bengkayang ini tentu berdampak pada kualitas lingkungan di kabupaten tersebut. Menurut data dari Kantor Lingkungan Hidup, Kebersihan, dan Pertamanan, 17.696 ha atau 3,2 persen wilayah Kabupaten Bengkayang sangat rawan banjir dan 82.806 ha atau 15,2 persen wilayah Bengkayang rawan banjir. Selain itu 1.266 ha atau 0,2 persen wilayah Bengkayang sangat rawan longsor dan 109.474 ha atau 20,1 persen wilayah Bengkayang rawan longsor.

Salah satu kendala yang sering muncul dalam pembangunan daerah di Kalimantan (selain juga persoalan infrastruktur dasar) adalah persoalan distribusi SDM yang tidak merata. Disparitas pembangunan di ibukota Kabupaten/Kota serta wilayah-wilayah perkotaan dengan perdesaan membuat migrasi lokal maupun mobilisasi warga tidak dapat dihindarkan. Bahkan migrasi juga terjadi terhadap para 
aparatur pemerintah daerah. aparatur yang pada awalnya ditempatkan di kecamatan atau desa setelah beberapa tahun mengajukan diri untuk pindah tugas di ibukota kabupaten/kota atau wilayah perkotaan lain. Hal ini berakibat menumpuknya aparatur pemerintah di kawasan-kawasan perkotaan terutama ibukota kabupaten/kota.

Di Kabupaten Kutai Barat (Kubar), berdasarkan informasi hasil wawancara dengan Sekretaris Bappeda Kabupaten Kubar, fenomena seperti ini juga terjadi misalnya terhadap tenaga pendidik. Berbagai upaya telah dilakukan Pemerintah Kabupaten Kubar yaitu pertama merekrut lulusan SMA dari warga lokal yang berada dalam satu kecamatan dengan sekolah yang memerlukan tenaga pendidik, kemudian mereka disekolahkan ke Perguruan Tinggi untuk jurusan khusus yang diperlukan, misalnya Bahasa Inggris, Matematika, Fisika, atau Biologi. Upaya ini dilakukan dengan menjalin kerja sama dengan perguruan tinggi untuk mendidik para calon guru tersebut dalam program Diploma 3. Pengembangan SDM juga dilakukan dengan memberikan beasiswa kepada mahasiswa, dan mengirimkan warga untuk sekolah dengan beasiswa ikatan dinas dalam rangka menyiapkan kebutuhan tenaga di bidang pendidikan. Selanjutnya mereka harus kembali setelah selesai menempuh pendidikan dan menjalani program PTT guru.

Oleh karena itu, disparitas merupakan isu penting dalam pembangunan, bukan hanya disparitas antara Jawa dan luar Jawa dalam konteks pembangunan nasional tetapi juga disparitas antar perkotaan dan perdesaan dalam pembangunan daerah. Disparitas ini bagaimanapun merupakan ekses dari pola pembangunan daerah yang cenderung lebih memperhatikan kawasan perkotaan tertentu dan terutama ibukota kabupaten/kota. Kurangnya perhatian terhadap pembangunan di kecamatan dan desa mengakibatkan minimnya sarana dan prasarana di kawasan tersebut dan berdampak pada meningkatnya migrasi warga ke perkotaan.

\section{E. PENUTUP \\ 1. Kesimpulan}

Berdasarkan uraian hasil temuan lapangan dan pembahasan terhadap dampak implementasi perencanaan pembangunan daerah di Kalimantan, maka dapat ditarik kesimpulan sebagai berikut:

a. Secara umum implementasi pembangunan daerah masih menjadi tantangan yang berat dilihat dari aspek ekonomi, sosial dan lingkungan, serta masih tingginya ketergantungan daerah terhadap hasil eksploitasi sumber daya alam. Hasil pembangunan daerah juga belum bisa dinikmati secara merata oleh masyarakat luas, dan belum bisa memberikan kontribusi positif jangka panjang bagi kesejahteraan masyarakat. Hal ini bisa terlihat di beberapa daerah yang memiliki kinerja pembangunan yang bagus ternyata ditopang oleh sumber daya alam yang tidak dapat 
diperbarui, seperti migas dan batubara, dan seringkali mengabaikan faktor lingkungan. Sementara di daerah lain yang tidak bisa mengandalkan potensi sumber daya alam mengalami kesulitan untuk mengakselerasi kinerja pembangunannya, bahkan masih ada daerah yang mengalami penurunan pertumbuhan ekonomi serta pe n ingkat a n j u m lah pengangguran. Sedangkan dari as pek fisik, terlihat pembangunan infrastruktur dasar, khususnya jalan di beberapa kabupaten cenderung lambat.

b. Dilihat dari dokumen perencanaan, realisasi pembangunan di beberapa kabupaten masih cenderung berorientasi pada output (output oriented). Dimana pemerintah daerah masih berorientasi pada pelaksanaan program dan kegiatan dan kurang memperhatikan manfaat dan dampak jangka panjang (dampak/outcomes) dari program dan kegiatan tersebut dalam bentuk yang seharusnya bisa dinikmati oleh masyarakat. Dengan kata lain, dampak positif yang diharapkan dari pembangunan daerah masih minim kontribusinya bagi kesejahteraan masyarakat.

\section{Rekomendasi}

Berdasarkan permasalahanpermasalahan yang ditemukan terkait dampak implementasi perencanaan pembangunan daerah di Kalimantan, dapat diberikan rekomendasi sebagai berikut :

a. Meningkatkan pertumbuhan ekonomi dan pembangunan daerah dengan memprioritaskan sektor ekonomi yang berbasiskan renewable resources. Sektor ekonomi berbasiskan sumberdaya yang dapat diperbaharui berpotensi untuk menjadi "lokomotif" ekonomi baru di masa yang akan datang, sebagai antisipasi terhadap berkurangnya sumberdaya alam yang tidak dapat diperbaharui.

b. Terus meningkatkan kualitas SDM melalui peningkatan pelayanan pendidikan dan kesehatan yang layak.

c. M e ndorong geraka n pembangunan hijau (green development) di semua sektor pembangunan. Pembangunan yang memperhatikan aspek lingkungan akan mengurangi tingkat pencemaran lingkungan, yang dampaknya akan sangat berarti di masa yang akan datang.

d. Dilakukan monitoring dan evaluasi secara berkala dalam rangka pencapaian target-target dalam RPJMD. Hal ini perlu dilakukan untuk melihat capaian setiap target yang ada dalam RPJMD sesuai dengan rencana 
yang telah dirumuskan.

e. Perlu ada perubahan paradigma pembangunan daerah dari yang berorientasi pada output ke outcome sehingga akan memberikan dampak pembangunan yang lebih optimal dan jangka panjang.

f. Meningkatkan kerjasama dengan daerah lain terutama dalam pengelolaan kawasan yang berbatasan dengan daerah lain, serta melibatkan swasta dan masyarakat dalam rangka mewujudkan pembangunan daerah yang partisipatif dan berkelanjutan. Hal ini agar semua pihak merasa bertanggungjawab atas keberhasilan pembangunan daerah.

\section{DAFTAR PUSTAKA}

A lmasdi Syahza, Dampak Pembangunan Perkebunan Kelapa Sawit Terhadap Multiplier Effect Ekonomi Pedesaan Di Daerah Riau, Pekanbaru: Lembaga Penelitian Universitas Riau, dalam http://almasdi. unri.ac.id/artikel_pdf/DAMP AK\%20PEMBANGUNAN \%20PERKEBUNAN $\% 20$ KELAPA\%20SAWIT\%20T ERHADAP\%20MULTIPLI
ER\%20EFFECT\%20EKON

OMI\%20PEDESAAN\%20D

I\%20DAERAH\%20RIAU1.

pdf diakses 19 Agustus 2011

Basri, Faisal, 2009, Catatan Satu Dekade Krisis; Transformasi Masalah Struktural, dan Harapan Ekonomi Indonesia, Erlangga, Jakarta

Bastian, Indra, 2006, Sistem Perencanaan dan $P$ e $n g a n g g$ ar $a n$ Pemerintahan Daerah di Indonesia, Penerbit Salemba Empat, Jakarta

Bratakusumah \& Riyadi, 2003, Perencanaan Pembangunan Daerah, Strategi Menggali Potensi dalam Mewujudkan Otonomi Daerah, PT Gramedia Pustaka Utama, Jakarta

Hamzens Wildani, 2005, Perencanaan di Indonesia, Penerbit Labdawara, cetakan kedua

Kartasasmita, Ginandjar, 1997, Administrasi Pembangunan, Perkembangan Pemikiran dan Praktiknya di Indonesia, Jakarta: LP3ES diunduh dari http://www.ginandjar.com/p ublications.asp tanggal 24 Juli 2008

Kuncoro, Mudrajat, 2006, Ekonomika Pembangunan: Teori, Masalah dan Kebijakan, Yogyakarta: UPP STIM YKPN, Ed.4 
Mahmudi, 2005, Manajemen Kinerja Publik. UPP AMP YKPN, Yogyakarta

Mustopadidjaja AR, 2009, Sistem Perencanaan, Keserasian Kebijakan, dan Dinamika Pelaksanaan Otonomi $D$ a e rah, d a 1 a m www.bappenas.go.id diakses pada tanggal 10 juli 2010

Riyadi dan Supriadi B., Deddy, 2005, Perencanaan Pembangunan Daerah, Strategi Menggali Potensi dalam Mewujudkan Otonomi Daerah, Jakarta: Gramedia Pustaka Utama, Cet-3

Solihin, Dadang, 2007, Perencanaan Pembangunan Daerah: Konsep, Strategi, Tahapan, dan Proses, diunduh dari http://www.slideshare.net/D adangSolihin/perencanaanpembangunan-daerahkonsep-strategi-tahapandan-proses/tanggal 14 Maret 2010.

Solihin, Dadang, 2008, Monitoring dan Evaluasi Perencanaan Pembangunan; dalam ADB, 2006, Impact Evaluation Methodological and Operational Issues, dalam www.dadangsolihin.com diakses pada tanggal 10 juli 2010.

Sudaryadi, 2007, Dampak Pembangunan Jalur Jalan Lintas Selatan Terhadap
Output Sektor Produksi dan Pendapatan Rumah Tangga Jawa Tengah, Thesis Magister Ilmu Ekonomi dan Pembangunan, Semarang: Program Pasca Sarjana, Universitas Diponegoro, dalam http://eprints.undip. ac.id/17971/1/Sudaryadi.pdf diakses 19Agustus 2011

Tarigan, Antonius, 2006, Mencermati Dampak Kebijakan Publik D a l a m Program $P$ enanggulangan Kemiskinan, dala m www.bappenas.go.id diakses 10 Juli 2010

\section{PERATURAN PERUNDANG-} UNDANGAN

Undang-Undang Nomor 25 Tahun 2004 Tentang Sistem Perencanaan Pembangunan Nasional (SPPN)

Peraturan Pemerintah Nomor 8 Tahun 2008 Tentang Tahapan, Tata $\mathrm{C}$ a r a P e y u s un a n, Pengendalian dan Evaluasi Pelaksanaan Rencana Pembangunan Daerah

Surat Keputusan Kepala Lembaga Administrasi Negara (LAN) Nomor 239/IX/6/8/2003 Tentang Pedoman Penyusunan Pelaporan Akuntabilitas Kinerja Instansi Pemerintah 